\title{
Context of validation of non-formal and informal learning in Spain: a comprehensive view
}

\section{María José Chisvert-Tarazona, Alicia Ros-Garrido, Míriam Abiétar-López \& Luis Carro}

To cite this article: María José Chisvert-Tarazona, Alicia Ros-Garrido, Míriam Abiétar-López \& Luis Carro (2019): Context of validation of non-formal and informal learning in Spain: a comprehensive view, International Journal of Lifelong Education

To link to this article: https://doi.org/10.1080/02601370.2019.1582563

\section{曲 Published online: 04 Mar 2019.}

Submit your article to this journal

View Crossmark data $ک$ 


\title{
Context of validation of non-formal and informal learning in Spain: a comprehensive view
}

\author{
María José Chisvert-Tarazona (D) ${ }^{a}$, Alicia Ros-Garrido (D) ${ }^{a}$, Míriam Abiétar-López (iD) \\ and Luis Carro ${ }^{\text {bic }}$
}

aFacultat de Filosofia i Ciències de l'Educació, Departament de Didàctica i Organització Escolar, Universitat de València, Valencia, Spain; 'bniversidad de Valladolid, Facultad de Educación y Trabajo Social, Valladolid, Spain; cPedagogy Department, Campus Universitario Miguel Delibes, Valladolid, Spain

\begin{abstract}
The system of validation and accreditation of professional qualifications in Spain is offered as a certification opportunity, especially for vulnerable groups. The procedure is presented as an evaluative proposal that allows some inequalities associated with training and employment to be addressed. In this article we analyse whether this system really fosters social cohesion, considering the political situation that frames the procedure and the educational approach underlying it. The research methodology combines the documentary analysis and interviews with the application of the Delphi method.

The most relevant results show that the socio-political context is favourable to competences accreditation, while the lack of expectations of the population, as well as of financial resources is hindering its implementation. The educational approach focused on learning outcomes and the evaluative control give the process an instrumental and credentialist value. The government intervention on the accreditation system can turn the procedure into a new instrument of political control of curriculum and education. Learning responsibility is shifted to those that access the procedure, both accrediting and generating new risks of exclusion. In conclusion, the system will offer inclusion opportunities if contextual aspects that humanise the procedure are taken into account.
\end{abstract}

\section{KEYWORDS}

Accreditation; validation; vocational qualification; vulnerability; socio-political context

\section{Introduction}

The European Centre for the Development of Vocational Training (Cedefop, 2012) and the European Council (Official Journal of the European Union, 2012) define the validation of nonformal and informal learning as the public, formal, and time-defined qualification of proven work capacity. The recognition of such capacity is not dependent on the prior completion of a learning process and should be related to the references expressed in a norm.

The context of the economic crisis, the disappearance of 'a job for life', the increased need for qualifications, and the high rates of early school dropout, present challenges for Europe in terms of expanding, updating, and validating available skills. Addressing these challenges has become an important driving force for education as well as for social policies and strategies (Hawley, SoutoOtero, \& Duchemin, 2011).

The Third Global Report on Adult Learning and Education (GRALE III) released by the United Nations Educational, Scientific and Cultural Organisation (UNESCO, 2016) analyses 
achievements in educational policies and includes results on the validation and accreditation of competences. This document, which has a holistic view of education and lifelong learning (Walters \& Watters, 2017), refers to results of the Global Observatory on the Recognition, Validation and Accreditation of Non-formal and Informal Learning: 71\% of a sample of 133 countries have a political framework to recognise, validate, and accredit non-formal and informal learning (UNESCO, 2016). They are non-formal and informal environments that contrast with formal education and claim the social significance of learning from personal experiences, in broad, diverse and flexible contexts (Eraut, 2004).

Lifelong learning does not always show patterns of social justice. There is evidence that young people, those who have high education levels, those who have a job, or those working in highly skilled occupations, are the ones more often involved in lifelong learning programmes (Boyadjieva \& Illieva-Trichkova, 2017; Roosmaa \& Saar, 2012). In this regard, Bukodi (2016) argues that lifelong learning mainly serves as a way of maintaining inequalities associated with social origins rather than reducing them. In fact, as Walker (2012) argues, the more privileged classes accumulate more resources and advantages, even in education.

Incorporating the validation and accreditation of professional qualifications into the educational policy discourse requires a reflective analysis on the impact of the socio-political and educational context in which they are implemented. The objective of this article is to analyse if this process inverts the current trend whereby the most vulnerable groups can take advantage of this resource. Therefore, we seek to know how contextual variables limit or expand the opportunities for the validation and accreditation of professional qualifications of these groups in Spain.

One of the keys to understand the validation and accreditation of skills is to analyse whether it is a mechanism of social and labour inclusion. Some authors argue that the validation of learning outcomes and their certification can offer new opportunities to people who did not have the chance to receive an education and qualifications (Souto-Otero, 2012). However, other authors consider that the certification, validation, and accreditation of learning outcomes in the labour market will be less accessible to people of a lower social status, those who are more vulnerable and have less formal accreditation (Marhuenda \& Bernad, 2008).

The goal of converting Europe into a knowledge-based economy has led to significant efforts by the European Union (EU), aimed at bringing Vocational Education and Training (VET) to work, at dignifying and promoting its access throughout a lifetime, and at facilitating the transitions of vulnerable groups into the labour market.

The management of learning outcomes based on qualification levels (Official Journal of the European Union, 2008) provides a landmark for the implementation of national qualification systems. Beyond the features of each country's development idiosyncrasies, the transparency in EU convergence has a public decision prerequisite, which regards the correlation of national or sectorial qualifications with the European Qualifications Framework (EQF), at all levels, whether university or VET. In Spain, although we can find antecedents in the access to university and to key occupations in the industry such as welders, air-conditioning or gas, the professional qualification accreditation processes started in 2009 , focusing on recognising work experience and non-formal training.

This article provides an approach to these processes through the vision of experts in the procedure and/or in how to deal with vulnerability in several professional fields. The research includes an analysis of the context in which they are carried out to confirm to what extent they are facilitators of social labour inclusion for vulnerable groups. The underlying question here is: Does the context in which qualification accreditation processes are carried out promote social justice? Social justice is understood here as institutional equity and as the individual capability to tap into available resources (Boyadjieva \& IllievaTrichkova, 2017; Sen, 2009). In order to clarify these questions, the article begins with a brief analysis on Lifelong Learning, especially on the Recognition of Prior Learning (RPL). Subsequently, we describe the methodology of the research conducted and the results relating to the contextual dimension of the accreditation of skills. Next, we introduce a discussion on these results, and ultimately the most relevant conclusions are included. 


\section{The recognition of prior learning: new opportunities in lifelong learning towards} social justice

Transitioning to a learning society requires a very active role of citizens (Duvekot, 2014). The International Commission on the Development of Education formulated a proposal of the UNESCO in which people and their social environment were linked for the first time in permanent education to offer everyone the opportunities of the learning society (Faure et al., 1972). Education could no longer be considered as a period before and different from active life. Although schooling is still the essential institution to transmit organised knowledge, it will be complemented with lessons learned throughout life in other contexts.

The recent history of permanent education has suffered the transformation of international policies. While UNESCO and the European Commission valued the democratisation of learning based on self-realisation and personal motivation in the 1970s (Holford, Jarvis, \& Griffin, 1998), the Organisation for Economic Co-operation and Development (OECD, 1973) insisted on a 'recurrent education' aimed at supporting economic growth and the training capacity of the workforce, cementing this approach in the 80s with the apogee of neo-liberalism. However, in 1992 Treaty of Maestrich gave a new twist in the formulation of European educational policies that sought to respond to trans-European social and cultural objectives. In this context, RPL was considered the cornerstone of lifelong learning. It was valued as an ascending process, which is born from individuality and can be linked to the theories of development economics, social choice and justice (Sen, 1999). The implementation of RPL followed the developmental policies of lifelong learning, with the exception of France, where legislation was introduced much earlier in 1934 (Duvekot et al., 2007). RPL was consolidated in the United States in the 1970s; it was developed in the United Kingdom, New Zealand, and Canada in the 1980s, and it was introduced in Australia and South Africa in the 1990s. These initiatives reflected the debate on lifelong learning policy, oscillating between social and economic perspectives.

However, the intention was not to leave the individuals alone in the validation, accreditation, and certification of their learning. In 1994 The European Round Table (ERT) of Industrialists encouraged employers to join governments to create a sustainable framework for expanding the availability of adult education, a reliable system for transferring credit between learning institutions, and a multifaceted cooperation between learning institutions, companies, and local authorities to facilitate access to educational opportunities (ERT, 1994). The OECD committed to the revised Lisbon Strategy of Europe in 2005 (Council of the EU, 2005), incorporating in its discourse the personalised and social nature of learning and its economic benefits.

Nowadays, the labour market performance and the answer to the economic requirements are at the centre of most decisions related to lifelong learning, even in the European Nordic countries, which are the most committed to learning for their own sake (Werquin, 2010). The European Commission (2010) in the Lisbon Agenda, adopted a relevant goal to turn the lifelong learning into a 'dynamic and competitive knowledge-based economy [...] capable of sustainable economic growth with more and better jobs and greater social cohesion and respect for the environment' (p. 2).

The ideological battle in lifelong learning has then resided within the learning strategies. In times of prosperity, educational policies have given higher priority to social objectives that are concerned with social change and citizen participation in the appropriation of the meaning and purpose of learning. In times of economic depression and recessions, the educational policies' focus has shifted to the employment and labour mobility agendas, with the aim of enabling economic growth and competitiveness.

In this political and ideological context in constant dialectic, a concept that recurrently emerges to show the benefits of the validation and accreditation of competences is vulnerability. SoutoOtero (2012) believes that if knowledge legitimises a professional group that is eligible for accreditation, it can contribute to improving the transition to training systems, the transparency 
in the labour market, and reducing social exclusion. An equation of the social status provided by the validation and accreditation system through the certification of qualifications is also claimed. Werquin (2010) argues that there are two problems in the recent literature about this area. First, degrees are not the sole determinants of social status: qualifications are a mirror where competences can be recognised. Secondly, there is a need to create plausible itineraries so that the individuals who do not fit into the traditional formal system may find a better position in the qualification system of their country.

Currently, vulnerability is a social construct derived from a weakened sense of citizenship and characterised by the fragmentation of wage relations due to several factors: unemployment, technological changes, limitations of social redistribution processes, and work individualisation. Vulnerable groups coexist with a high risk of social exclusion and with questioning their citizenship (Castel, 2004). Paradoxically, exclusion concerns those who are in the margins of society and who, simultaneously, are a necessary part of it. Within this zone of vulnerability, social devices, such as validation processes, operate (Karsz, 2000). In the European context, Andersson \& Osman's (2008) investigation about a project in Sweden aimed at developing methods for validating recent immigrants' prior learning analysed how RPL acts as a dividing practice. In the process of recognition, the targeting of certain vocations for assessment, the degrading of competence in the process, and the differing opportunities that offer the labour market bring on the exclusion of immigrants in their vocations in Swedish working life. Diedrich (2013) suggests that the difficulties experienced in this project may be explained by its emphasis on procedural efficiency over a more comprehensive understanding of the diverse nature of the immigrants' skills. Also, outside Europe, we find criticism of the procedure in its application to vulnerable groups. Guo and Shan (2013) argued that government documents concerning PRL have established Managerialism, which has served to strengthen the monopolistic power positions of the Canadian regulatory bodies to delimit valid knowledge, skills, and standards.

However, there are also European suggestive initiatives that bring us closer to inclusive RPL proposals. In Portugal, the New Opportunities Initiative was a validation and accreditation procedure that between 2006 and 2011 was aimed at improving adult education and sparked a great social movement thanks to the revision and certification of basic and academic qualifications (Capucha, 2014). The procedure had a great ability to adapt to the diversity of applicants and also being attentive to the contextual variables.

\section{Research method}

The assumptions made at the start of this research in the Spanish context are: (1) The sociopolitical situation favours the implementation of the procedures for the accreditation of skills, regardless of the unwillingness of the education and labour authorities; and (2) vulnerable groups have fewer opportunities to access the process of validation and accreditation of skills.

The methodological strategy combines document analysis with interviews with experts and the development of the Delphi method, in which they intervene in order to assess the results obtained by the research team.

\section{Document analysis}

The document analysis derived from the in-depth review of bibliographical and hemerographic material aims to provide a description of the development of the accreditation of professional qualifications in the European context, particularly in Spain. This review enabled an initial screening of three units of analysis (Figure 1): sampling (referring to document units comprising the sample to be analysed), contextual (referring to the portion of the sampling unit separately analysed for its meaning) and recording (referring to analysable concepts which the context units are divided into: keywords). 


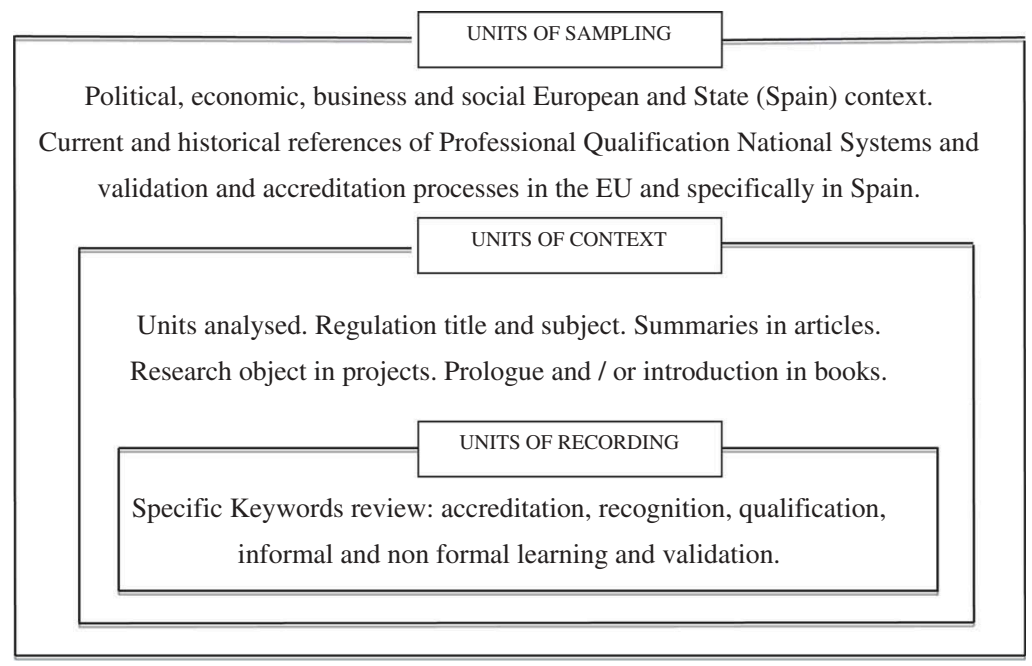

Figure 1. Content analysis of documentary sources.

Source: Authors' compilation.

One hundred and seventy texts have been selected as sampling units, from which a total of 58 have been cited in this article. Figure I shows the defined units of analysis. The data collection technique was an ordinal scale prepared by the research team. This scale introduces fields related to the bibliographic reference and a summary of the most significant contributions. Consulted sources included the WOS, ERIC and Dialnet databases, Cedefop, OECD, ILO, European and Spanish data, Official Journal (BOE), specialised journals and our own references.

The documentary analysis is comprised of three phases: literature search, verifying information, and historical/current analysis. The literature findings enabled a textual review and a first screening of the units of analysis introduced in Figure I. The second phase, verifying information, addressed the intertextual comparison and confirmation of the selected material. The third phase allowed a study of the evolution of knowledge on the validation and accreditation of qualifications, its connections with other European qualification systems, and its current meaning as an education policy.

\section{Semi-structured interviews and Delphi method}

Sixteen specialists were interviewed in order to determine the possibilities that the implementation of the accreditation procedures offers to groups at risk of social exclusion. As Flick (2009) notes, the respondent is of interest in his/her quality as an expert in this field of study, which is why we selected people from the following areas: academic research on evaluation, accreditation and Vocational Training; director of the Validation of Professional Skill Boards Centre; union representation in the General Council of VET; entities for integration represented by national and private sectors; directors of the National and Regional Institutes of Professional Qualifications, as well as independent institutions; training assessors and advisors of the National System for Qualifications, and Vocational Education and Training; evaluation and counselling. The semistructured interview was validated by members of the Occupational Training Research Group of the Autonomous University of Barcelona and a professor of the University of Castilla-La Mancha. Interview quotes have been selected considering saturation, clarity of exposition and relevance for the research criteria.

The Delphi method allowed the analysis of the first results obtained from the consulted secondary sources and the interviews. The aim of this method is to create a collective view of 
experts on a subject, which in our case is on accreditation and its impact on vulnerable groups. The key lies in the successive reiteration of a questionnaire. In this research, two phases were carried out and the mean results were fed back into the second round, in order to reach a consensus.

The number of participants in the Delphi method, 16, was within the range of appropriateness proposed by various experts (Cabero \& Infante, 2014; Landeta, 2002). The heterogeneity of the participants and the anonymity of their responses prevented the effects of the dominating group and ensured the validity of the results (Cabero \& Infante, 2014), favouring a more enriching exchange. The assertions made permitted the introduction of a forum for discussion that helped to understand the social reality. Participants were able to make observations and assess the suitability (agreement/disagreement with the affirmations) and relevance (interest rate by reference to the aim of the research) of each of the statements of the survey. Participants in research have given informed consent for exploitation.

Following indications of Guba (1983) on the application of qualitative methodology, saturation was the strategy of credibility followed, consisting in gathering sufficient evidence from the repetition of contributions in the interviews and contributions in the Delphi. With regards to applicability, descriptive and interpretive statements were provided allowing comparison with similar contexts, thus endowing consistency. Neutrality was taken into account by making the initial methodological assumptions explicit.

\section{Results and discussion}

The results presented in this article refer to the socio-political situation regarding validation and accreditation of qualifications in Spain, and the educational approach focused on learning outcomes that act as the basis of these procedures. The factors of this contextual dimension, which connect the results of the literature review, interviews (the citations are referenced with a specific code for each person) and the Delphi method (the results are reported in Tables 1 and 2) are discussed below.

\section{Socio-political situation}

Four factors have been considered as the context for the rise of qualification accreditation systems in Europe and Spain:

\section{(F1) High percentages of unqualified people in Europe, especially in Spain}

The growing complexity of knowledge and technology applied to production requires more qualified professional profiles. This trend favours an increase in inequality as globalisation increases the need for more skilled labour and reduces the chances of low-skilled workers (Steinberg, 2013). This situation is worse in Spain if one compares the employed population and the qualification levels. In Spain, there is an evident and deep imbalance in the levels of education of the employed population, where a lack of qualification coexists with overqualification (Homs, 2008), whereas in Europe the higher occupation rates consist of people with intermediate qualification levels. In fact, according to the Labour Force Survey in Spain, data from the second quarter of 2018 depicts that the population with non-professional qualification levels reached $49.71 \%$.

Through the Delphi, most of our informants stated that the lack of accredited qualifications is a stimulus to advance to the processes of evaluation and accreditation of professional skills that are acquired through work experience or non-formal training (Statement 1, Table 1). As an evaluator and advisor trainer expressed in the interviews: 'On having a high rate of low-skilled workers, officially qualified, this process is specifically aimed at recognising the official status of their skills, which they can capitalise on' (EDJ). 
INTERNATIONAL JOURNAL OF LIFELONG EDUCATION 7

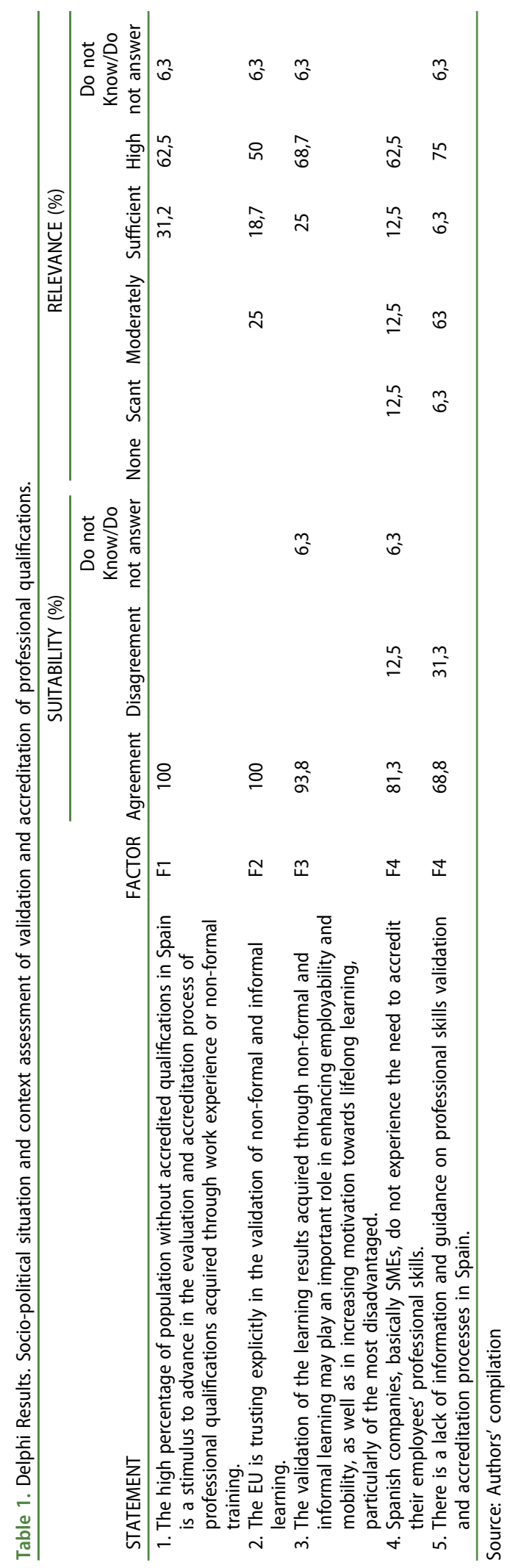




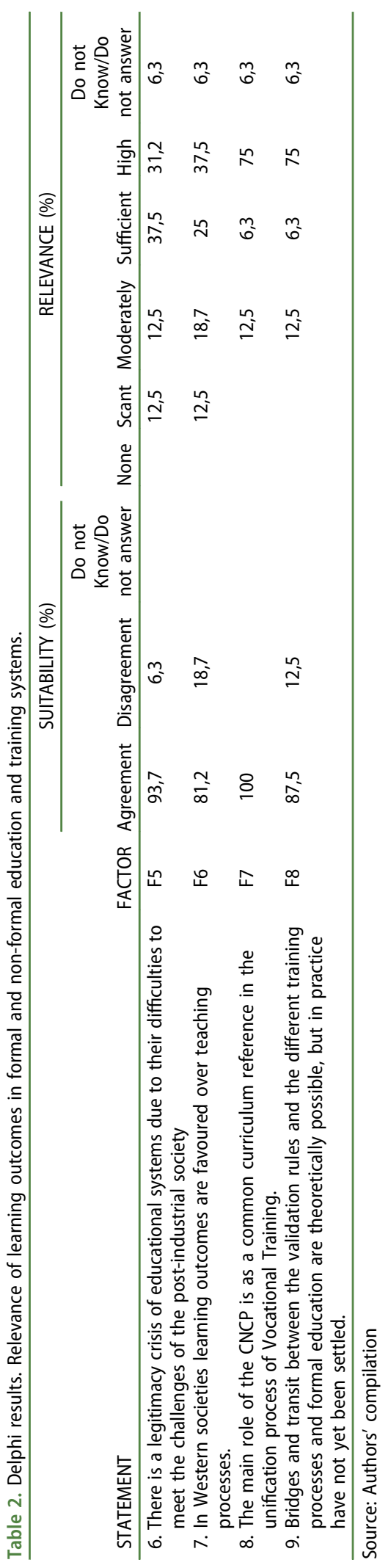




\section{(F2) EU institutional support for the validation and accreditation of competences}

This factor is considered key by those consulted in the Delphi (Statement 2, Table 1), and it is also evidenced by the results of the documentary analysis. In this regard, the Copenhagen Declaration of 2002 urged the development of common principles for the validation of non-formal and informal learning. The aim was to ensure comparability between the approaches taken by different countries. Initiatives in this direction emerge, like the common European Principles for the recognition and validation of non-formal and informal learning (European Council, 2004), the European Guidelines for validating this learning (Cedefop, 2010), or the European inventory on validation of such learning, where EU Member States' policies and method issues are compiled (Colardyn \& Bjornavold, 2005) and constantly updated. Currently, the European Council's recommendations (Official Journal of the European Union, 2012) promote greater cooperation and social cohesion, by supporting national policies and practices in the area of validation of nonformal and informal learning. In fact, one of the most outstanding European 2020 Initiatives is the EU's growth strategy for this decade, which includes the agenda of new qualifications and jobs, predicting a decrease of 20 million in the number of people at risk of poverty and social exclusion in 2020 (European Commission, 2010).

Based on the European Inventory on the validation of non-formal and informal learning projects, chiefly its 2014 update, as well as a review of 124 EU-funded (Lifelong Learning Programme and European Social Fund) validation projects, Souto-Otero and Villalba-García (2015) present this finding: In terms of country clusters, the tendency to consider immigrants to be a dominant target group for validation is greater in Central European and Nordic countries than in Southern and Eastern European countries.

The complexity of the validation of such learning means that there are different levels of decision-making in each country involving the coordination of various institutions and sectors (public, private, and voluntary). There is an intensive discussion about how to integrate them into national qualification frameworks, but few countries have reached a clear coordination. When considered at a developmental level, the environment is quite mixed (Bjornavold \& Le Mouillour, 2009; European Commission, Cedefop \& ICF International, 2014), with the existence of different definitions of these processes at regional and national levels in the different EU countries.

The most recent European inventory on the validation of non-formal and informal learning (Cedefop, 2016) shows how some countries and regions in the EU are lagging in the recognition of education and learning. This report considered that the efforts made in Spain are not enough to reach out to all possible beneficiaries. To avoid these situations, they are asking for greater EU presence in governance policies. This is confirmed in some interviews: 'In Europe there are many impulses but no common method (...) convergent processes have not been reached' (EFA). The Committee of the Regions (Official Journal of the European Union, 2015) believes that the proposed measures cannot be sufficiently well performed by the Member States, and it would be better to bring them to the EU level. This statement announces policy recommendations for the creation of a pan-European strategy (which would limit the decisions of states, regions, and local authorities) as guidelines, and possible implementation scenarios to establish legal frameworks and common minimum standards for the recognition of education and non-formal and informal learning. Thus, the EQF aims to be the conversion mechanism that ensures the readability of European qualifications systems, comparing qualifications, frameworks of national systems and its levels, and incorporating guidelines and mandatory standards. In the words of an expert: 'The European Qualifications Framework in VET is actually mandatory because it affects the free movement of workers. It is thus an employment regulation' (EDJ). If this regulation does not take into account national specificities, the most vulnerable groups, with fewer resources and greater need for mobility to access a job, will be negatively affected. The great difficulty is that the practices are determined by supranational objectives that do not always allow national specificities to arise (Cavaco, Lafont, \& Pariat, 2014). 
(F3) Low expectation of the Spanish administration in the implementation of the accreditation of skills processes

The European institutional discourse is transferred to the discourse of education and labour authorities in Spain. The National Institute of Qualifications (INCUAL) clarified on its website that the validation and accreditation of skills are relevant for employment, mobility, and motivation towards lifelong learning, especially among vulnerable groups. Experts also place importance on this factor in the Delphi (Statement 3, Table 1). However, it contrasts with the little hope of the Spanish labour and educational authorities for the implementation of the accreditation of qualification processes due to the limited resources for calls, dissemination of the process, training of professionals for its development, or updating of the National Catalogue of Professional Qualifications (CNCP). Most of the people interviewed questioned the commitment of the Spanish political institutions: 'Two decades have passed with more or less crisis, or more or less of an economy boom, but in the end, [the accreditation of skills] is something that has not been dealt with, despite the guidelines set by Europe' (ERG). Yet another interviewee justifies that, in many cases, the agents that intervene at government level believe in the appropriateness of promoting the system, but do not have the means, 'despite [the limited resources] this does not mean that there are people in the administration who do not believe and support the procedure, but they find that there is an absolute lack of means' (EDJ).

The limited resources at the onset of this validation and accreditation of skills process in Spain is being especially difficult to endure by vulnerable groups. This is due to the limited calls in the regions that address level one qualifications, or the difficulties to enter the process, given the small number of places offered [Anonimised].

\section{(F4) Low expectations for learning and recognition of skills by business people and workers}

Training in companies in Spain stand at $21.2 \%$ in 2017, with microenterprises participating to a lesser extent, with a coverage rate of $16.8 \%$ (Fundación Estatal para la Formación en el Empleo, 2018). In the opinion of experts, this interest is low in the case of micro, small and medium-sized companies: 'The continuing training systems we have articulated are designed for large companies, but not for the large mass of companies that exist in Spain, which are small and specifically micro' (EAN). Meanwhile, businesses have not experienced the need to accredit the skills of their employees (Statement 4, Table 1). As one academic expert in VET says:

\footnotetext{
'The recognition of skills would have to be linked to a certificate and would also have to be reflected in the works agreements, namely recognition in terms of salary and working conditions. It is not something that particularly interests the entrepreneurial tradition, that seems to seek short-term profit and tends to see the workforce as a lesser priority which it must take into consideration when running a business' (EFM).
}

In this regard, the situation of the labour market seems to require a collective imagination in order to assume a change. Continuing VET, which is considered a basic requirement to address the required level of professional quality, encounters resistance in several sectors of society. In agreement with Bukodi (2016) and Walker (2012), we have found that the most qualified are those who gain access to resources of the qualification systems:

\footnotetext{
'Those who use the systems of non-formal and informal qualifications the most are educated people with high levels of education. Hence, a paradox occurs: in England they refer to it as the Matthew effect principle, those who have more, will be given more' (EMS).
}

A lack of information and guidance was found with respect to the validation and accreditation of skills process (Statement 5, Table 1). Only regulated professions have experienced the need for accreditation. 


\section{The relevance of learning outcomes}

The educational context provides four new explanatory factors that contextualise the accreditation process:

\section{(F5) The legitimacy crisis of education systems: from training to learning}

The deep legitimacy crisis of education systems was already evident in the 1970s (Faubell, 1973). Doubts about the hegemony of education systems as unique knowledge providers (Eraut, 2004) are especially evident with the entry of an institutional discourse that favours learning skills (Council of the EU, 2012).

This crisis transcends VET, too. The general trend in the EU Member States shows evidence of an increasing unsuitability of the VET qualifications and systems to the demands of the labour market (European Commission, 2013; Official Journal of the European Union, 2015).

New educational networks are formed, displaying awareness of the gaps in teaching and learning that is acquired in schools. To take advantage of these synergies, but also to respond to new production needs of European States, an inclusive discourse of these new spaces is applied: the information and knowledge society requires lifelong learning. The legitimacy crisis in the education systems is confirmed in the Delphi, (Statement 6, Table 2) which is considered relevant to the qualification accreditation processes.

This integration discourse of lifelong learning, sustained by authors like Giddens (1991) and Duvekot (2014), houses a deep and invisible mechanism that increases the role of individuals in their acquisition of knowledge, skills, and competences in their learning process, which proportionally reduces the State responsibility. One of its basic features is that it does not matter where or how the knowledge is accessed: what matters is what has been learned. In comparison, some institutions are concerned about guaranteeing the learning processes: Second Chance Schools (SDE), Centres for Adult Education, the organisations of Occupational Training (Prokou, 2008) and Work Integration Social Enterprises (Chisvert-Tarazona, Ros-Garrido, Córdoba-Iñesta, \& Marhuenda-Fluixá, 2015) organise a network of formal and non-formal activities aimed at people who have not completed compulsory schooling. This reflection leads us to the next factor.

\section{(F6) The relevance of learning outcomes}

Learning outcomes begin to be reviewed by education and employment policies that reduce concern about the rationale of teaching. This position argues that, once the required results are defined, we only need to reliably and independently measure performance in the environment in which it was learned. The majority of the experts consulted in the Delphi agreed that Western societies favour learning outcomes (Statement 7, Table 2).

Currently, the relevance of educational outcomes opens opportunities for recognition of learning produced in other educational environments. It is a fact, and it is assumed that learning is no longer confined to schools. In this context, the emphasis on education is no longer placed on equal access to education (Souto-Otero, 2012). It is about making the knowledge generated in different contexts visible, recognising the power of non-formal and informal spaces to generate skills and competences that are equivalent to those produced in the education systems (Bjornavold, 2000). For Raffe (2009), the differences offered by several teaching/learning contexts refer to social, not epistemological, constructions. Supporters of this approach believe that focusing on results avoids overlapping, allows the recognition of prior learning, creates transparency in the labour market, and promotes second chances for groups that left educational institutions prematurely, which enables new transitions across the education system or expanding their opportunities in the labour market.

Some of the critics of this approach argue that policy instruments associated with learning will soon define and control assessment practices and curriculum (Guo \& Shan, 2013; Leney, Gordon, \& Adam, 2008). The validation of prior learning should be regarded as a process rather than 
a result (Diedrich, 2013). The quality of the learning obtained in non-formal and informal milieux is also questioned. Accordingly, Young (2008) argues that educational institutions can and should convey and create a different kind of knowledge: a 'powerful knowledge' that allows access to a broad understanding of the processes and that is difficult to access from other non-formal or informal spaces. There are also those who argue that this approach shifts the responsibility to those who access, or do not access learning. Its instrumental value exchange is added to the list of collectable properties. Credentialism, as Collins (1979) warned decades ago, is still valid: cultural capital is heavily marked by social and political factors, and thus, it strongly benefits those who have better training and labour opportunities. Extensive similarities of learning outcomes to learning objectives are also worth noting: what happens during the teaching process is overlooked.

(F7) The CNCP as a curriculum source that articulates the VET subsystems

There is a need for a regulatory reference of the VET curriculum. The definition introduced by INCUAL (2014) is conclusive with respect to the CNCP being an instrument of the National System for Qualifications and Vocational Education and Training listing professional qualifications that can be trained, recognised and accredited, identified in the production system according to the appropriate professional performance' (p. 4). This catalogue becomes the curriculum that allows articulating VET subsystems, as expressed by all the experts (Statement 8 , Table 2). It is also concerned with the procedures for the validation and accreditation of professional qualifications.

This common normative framework broadens access opportunities to VET and adult education, whose empowerment and promotion have been considered a key action by the Spanish government to upgrade qualification levels, reduce the polarisation of skills, and bring about economic growth (Hawley et al., 2011). However, its update rate was questioned by some of the respondents, who consider it a very relevant key to the labour market. As one academic expert said: 'The intention is for the catalogue of qualifications to fit the market, (...) however new jobs, new demands, new needs are continually emerging and the changes in the catalogue happen slowly' (ELC). This is particularly disturbing at qualification level 1, where there are fewer professional qualifications, which is something that has a much larger impact upon the most vulnerable groups (Chisvert-Tarazona et al., 2015) .

(F8) The feasibility of bridges and transitions between learning acquired from non-formal and informal ways, and formal education

The Strategic Framework for Cooperation in Education and Training 2020 (European Commission, 2010) identified 'making lifelong learning a reality' as the first strategic objective to be addressed in this decade.

This factor shows a broad consensus among those consulted and points to the theoretical possibility of moving between different learning pathways, but it also refers to the existence of difficulties in terms of practice (Statement 9, Table 2). The right to work mobility in Europe can only be guaranteed if instruments such as the EQF, which incorporate conversion mechanisms between EU countries, are available. As one academic expert in VET said: 'The EQF is meant to defend the mobility and it is also responsible for building bridges' (EJT).

In Spain, the CNCP has been the mainstay of VET due to its integration power, allowing for the inclusion of new validation and certification mechanisms of learning. Meanwhile, practical constraints continue to be detected in the procedure to ensure access to continuing VET and to allow movement throughout the different training subsystems, ensuring the development and certification of learning that is acquired in formal, non-formal, and informal settings. The training is not available in time, nor is it available to the people who wish to use it. It does not respond to the needs of vulnerable groups, either. Thus, this interrupts their transition process and even bringing them to a standstill. 


\section{Conclusions}

The validation and accreditation of skills are being developed in Spain in a socio-political situation, determined by a lack of funding and by an approach that focuses on the outcomes of the education processes and on their evaluation.

Our first research aim is fulfilled by observing how the current socio-political situation promotes the validation and accreditation of skills. This is proof of the multiplication and diversification of social and labour transitions, the consolidation of VET policies, European approval and its active position towards convergence in this area, and the emergence of educational approaches that emphasise educational outcomes versus processes. European States require a qualified and properly certified population. It is also remarkable that a procedure that allows visibility of something that was formerly hidden to the governing authority is a power device. Therefore, the validation and accreditation of qualifications empower those who take advantage of certification, but, also, it is a process of social control and regulation, exercised mostly by the Member States. However, in Spain, this fact clashes with a lack of political will of the education and labour authorities, which have not earmarked enough resources for its execution.

Referring to the second aim, the experts considered that legislative procedures show how vulnerable groups have fewer opportunities to access the validation and accreditation of qualifications. Thus, the analysis of the context also leads to reinforce the need of an approach of social justice. A system that credits discredits: it expands social rights to the extent that it recognises and gives visibility to already acquired knowledge, but it is also a selective process that introduces a new risk of exclusion. If we focus on learning outcomes and ignore the processes, we shift the responsibility of learning to the people, and the most vulnerable groups may not be able to bear this burden. Accreditation acquires an instrumental value of change, in which certification is sought to obtain a commodity that can be accumulated in order to facilitate access to the labour market. In order to modify this situation, lifelong learning programmes should sustain the accreditation system to become a welcoming space for these groups.

Accreditation processes could become an opportunity if the regulatory stakeholders became aware of the importance of facilitating the inclusion of vulnerable groups. One of the keys to promoting a suitable validation and accreditation procedure of professional knowledge is a social construction process that requires consultation, agreement, and a closer look at contextual issues. This would tilt the balance towards inclusion, humanising a process that tends to hide diversity under a discourse of objectivity, neutrality and reliability, with the risk of becoming just another instrument towards segregation.

\section{Disclosure statement}

No potential conflict of interest was reported by the authors.

\section{Funding}

This work was supported by the Universitat de València under Grant UV-INV-PRECOMP13-115340.

\section{Notes on contributors}

María José Chisvert-Tarazona holds a Ph.D. in Philosophy and Educational Sciences. She is an assistant professor in the Department of Didactics and Scholar Organization in the University of Valencia (Spain) and member of the research group 'Transitions to the working world in at-risk populations'. Her lines of research are related to the accreditation of professional qualifications, vocational training and guidance and social entrepreneurship. She has been the main researcher of a project concerning the accreditation of qualifications in vulnerable groups financed by the University of Valencia (2013-2014). 
Alicia Ros-Garrido is Ph.D. in Pedagogy. She is an assistant professor in Didactics and Scholar Organization at the University of Valencia (Spain). Her research interests focus on continuing vocational education, accreditation of learning, and how to bring these issues into the education of vocational education and training teachers and trainers. Before entering university, she has herself been a vocational trainer as well as a counsellor. She is member of the research group 'Transitions to the working world in at-risk populations'.

Míriam Abiétar-López holds a M.A. in Youth and Society from the University of Girona and a Ph.D. in Education from the University of Valencia (Spain). She is an assistant professor in the Department of Didactics and Scholar Organization at the University of Valencia. Her work is focused on the development of a conceptualization of social justice applied to the analysis of educational programs and to the role the play in the transitions of youth at risk of educational and social exclusion.

Luis Carro Sancristóbal holds a Ph.D. in Philosophy and Educational Sciences. He is tenured lecturer in the Department of Pedagogy in the University of Valladolid. He is the director of the Observatory of the Validation of Professional Competences (OBSERVAL). His recently work is focused on the development of the validation and accreditation of professional competences.

\section{ORCID}

María José Chisvert-Tarazona (iD) http://orcid.org/0000-0002-5533-8100

Alicia Ros-Garrido (iD http://orcid.org/0000-0002-6968-0900

Míriam Abiétar-López (iD) http://orcid.org/0000-0003-2082-2434

Luis Carro (iD) http://orcid.org/0000-0003-1807-7076

\section{References}

Andersson, P., \& Osman, A. (2008). Recognition of prior learning as a practice for differential inclusion and exclusion of immigrants in Sweden. Adult Education Quarterly, 59(1), 42-60. doi:10.1177/0741713608325173

Bjornavold, J. (2000). Making learning visible: Identification, assessment and recognition of non-formal and informal learning in Europe. Luxembourg: Office for Official Publications of the European Communities.

Bjornavold, J., \& Le Mouillour, I. (2009). Learning outcomes in validation and credit systems. European Journal of Vocational Training, 48(3), 27-47.

Boyadjieva, P., \& Illieva-Trichkova, P. (2017). Between inclusion and fairness: social justice perspective to participation in adult education. Adult Education Quarterly, 67(2), 97-117. doi:10.1177/0741713616685398

Bukodi, E. (2016). Cumulative inequalities over the life-course: Life-long learning and social mobility in Britain Working Paper No. 16-02. Oxford: University of Oxford. doi: 10.1017/S0047279416000635

Cabero, J., \& Infante, A. (2014). Empleo del método Delphi y su empleo en la investigación en comunicación y educación [Use of the Delphi method and its use in research in communication and education]. EDUTEC, Revista Electrónica de Tecnología Educativa, 48, 1-16.

Capucha, L. (2014). Iniciativa Novas Oportunidades, o tempo da Igualdade [New Opportunities Initiative, the time of Equality]. In M. L. Rodrigues (Ed.), 40 anos de políticas de educação em Portugal (pp. 393-410). Coimbra: Almedina.

Castel, R. (2004). La inseguridad social. ¿Qué es estar protegido? [the social insecurity. What does being protected mean?]. Buenos Aires: Manantial.

Cavaco, C., Lafont, P., \& Pariat, M. (2014). Policies of adult education in Portugal and France: The European agenda of validation of non-formal and informal learning. International Journal of Lifelong Education, 33(3), 343-361. doi:10.1080/02601370.2014.896086

Cedefop. (2010). The development of national qualifications framework in Europe August 2010.Working Paper, Luxembourg: Publications Office of the EU. pp. 8

Cedefop. (2012). Development of national qualifications frameworks in Europe. October 2011. Luxembourg: Publications Office of the EU.

Cedefop. (2016). European inventory on validation of non formal and informal Learning. Luxembourg: Publications Office of the EU.

Chisvert-Tarazona, M. J., Ros-Garrido, A., Córdoba-Iñesta, A., \& Marhuenda-Fluixá, F. (2015). Mapa de cualificaciones profesionales acreditables en las empresas de inserción. [Map of Accreditable Professional Qualifications in Work Integration Social Enterprises]. Certiuni Journal, 1, 36-50.

Colardyn, D., \& Bjornavold, J. (2005). The learning continuity: European inventory on validating non-formal and informal learning national policies and practices in validating non-formal and informal learning. Luxembourg: Office for Official Publications of the European Communities. 
Collins, R. (1979). The credential society: A historical sociology of education and stratification. New York, NY: Academic Express.

Council of the EU. (2005). Presidency conclusions, March 22 and 25, 2005. (7619/ 1/05REV 1). Brussels: EU

Council of the EU. (2012). Council recommendation of 20 December, 2012 on the validation of non-formal and informal learning. (2012/C 398/01). Brussels: EU.

Diedrich, A. (2013). Translating validation of prior learning in practice. International Journal of Lifelong Education, 32(4), 548-570. doi:10.1080/02601370.2013.778078

Duvekot, R. C. (2014). Lifelong learning policy and RPL in the learning society: The promise of Faure?. In J. Harris, C. Wihak, \& J. V. Kleef (Eds.), Handbook of the recognition of prior learning (pp. 65-85). Wales: National Institute of Adult Continuing Education (NIACE).

Duvekot, R. C., Scanlon, G., Charraud, A., Schuur, C. C. M., Coughlan, D., Nilsen-Mohn, T., ... Klarus, R. (Eds.). (2007). Managing European diversity in lifelong learning. The many perspectives of the valuation of prior learning in the European workplace. Nijmegen: HAN/EC-VPL/HvA.

Eraut, M. (2004). Informal learning in the workplace. Studies in Continuing Education, 26(2), 247-273. doi:10.1080/ 158037042000225245

ERT. (1994). Education for Europeans: Towards the learning society. Brussels: Author.

European Commission. (2010). Communication from the commission Europe 2020. A strategy for smart, sustainable and inclusive growth. Brussels: Author.

European Commission. (2013). Labour market developments in Europe. Brussels: Author.

European Commission, Cedefop \& ICF International. (2014). European inventory on validation of non-formal and informal learning 2014 (Thematic report: awareness raising). Brussels: Author.

European Council. (2004). Draft conclusions of the council and of the representatives of the governments of the member states meeting within the council on common European principles for the identification and validation of non-formal and informal learning. Brussels: Author.

Faubell, V. (1973). La escuela contestada. ¿Desescolarizar o reevaluar? Revista de Ciencias de la Educación, 73, 9-40.

Faure, E., Herrera, F., Kaddoura, A., Lopes, H., Petrovsky, A. V., Rahnema, M., \& Champion-Ward, F. (1972). Learning to be: The world of education today and tomorrow. Paris: UNESCO.

Flick, U. (2009). An introduction to qualitative research. London: Sage.

Fundación Estatal para la Formación en el Empleo. (2018). Training for employment. Key findings 2017. Retrieved from https://www.fundae.es/Observatorio/Pages/Balance-de-resultados.aspx

Giddens, A. (1991). Modernity and self-identity: Self and society in the late modern age. Cambridge: Polity.

Guba, E. G. (1983). Criterios de credibilidad en la investigación naturalista [Criteria of credibility in naturalistic inquiry]. In J. Gimeno \& Á. Pérez (Eds.), La enseñanza: Su teoría y su práctica (pp. 148-165). Madrid: Akal.

Guo, S., \& Shan, H. (2013). The politics of recognition: Critical discourse analysis of recent PLAR policies for immigrant professionals in Canada. International Journal of Lifelong Education, 32(4), 464-480. doi:10.1080/ 02601370.2013 .778073

Hawley, J., Souto-Otero, M., \& Duchemin, C. (2011). 2010 update of theEuropean inventory on validation of nonformal and informal learning - final report. Brussels: European Commission.

Holford, J., Jarvis, P., \& Griffin, C. (1998). International perspectives on lifelong learning. London: Kogan Page.

Homs, O. (2008). La formación profesional en España [vocational training in Spain]. Barcelona: La Caixa.

INCUAL. (2014). Catálogo Nacional de las Cualificaciones Profesionales [national catalog of professional qualifications]. Madrid: Secretaría General Técnica, Ministerio de Educación, Cultura y Deporte.

Karsz, S. (2000). L'exclusion, définirpour en finir [Exclusion, define to finish]. Paris: Dunod.

Landeta, J. (2002). El método Delphi: Una técnica de previsión para la incertidumbre [the delphi method: A forecasting technique for un certainty]. Barcelona: Ariel.

Leney, T., Gordon, J., \& Adam, S. (2008). The shift to learning outcomes: Policies and practices cross Europe. Thessaloniki: European Centre for the Development of Vocational Training.

Marhuenda, F., \& Bernad, J. C. (2008). El sistema de cualificación profesional en España y los/as trabajadores/as escasamente cualificados/as [The professional qualification system in Spain and the low qualified workers]. Revista Europea de Formación Profesional, 42/43, 91-102.

OECD. (1973). Recurrent education: A strategy for lifelong education. Paris: Author.

Official Journal of the European Union. (2008). Recommendation of the European parliament and of the council of 23 April 2008 on the establishment of the European qualifications framework for lifelong Learning, C111/1, 6-5-2008. Brussels: Author.

Official Journal of the European Union. (2012). Council recommendation of 20 December 2012 on the validation of non-formal and informal learning. 2012/C 398/01, 22-12-2012. Brussels: Author.

Official Journal of the European Union. (2015). Opinion of the committee of the regions. Recognition of skills and competences acquired through non-formal and informal learning. 2015/C 019/16, 21-01-2015. Brussels: Author.

Prokou, E. A. (2008). A comparative approach to lifelong learning policies in Europe: The cases of the UK, Sweden and Greece. Sweden European Journal of Education, 43(1), 123-140. doi:10.1111/ejed.2008.43.issue-1 
Raffe, D. (2009). The action plan, Scotland and the making of the modern educational world: The first quarter century. Scottish Educational Review, 411, 22-35.

Roosmaa, E. L., \& Saar, E. (2012). Participation in non-formal learning in EU-15 and EU-8 countries: Demand and supply side factors. International Journal of Lifelong Education, 31, 477-501. doi:10.1080/02601370.2012.689376

Sen, A. (1999). Development as freedom. Oxford: Oxford University Press.

Sen, A. (2009). The idea of justice. London: Penguin Books.

Souto-Otero, M. (2012). Learning outcomes. Good, irrelevant, bad or none of the above? Journal of Education and Work, 25(3), 249-258. doi:10.1080/13639080.2012.689648

Souto-Otero, M., \& Villalba-García, E. (2015). Migration and validation of non-formal and informal learning in Europe: Inclusion, exclusion or polarisation in the recognition of skills? International Review of Education, 61, 585-607. doi:10.1007/s11159-015-9516-7

Steinberg, F. (2013). Europa y la globalización: De amenaza a oportunidad [Europe and globalization: From threat to opportunity]. Work document of the Real Instituto Elcano, 7/2013, pp. 1-18.

UNESCO. (2016). 3rd Global Report on Adult Learning and Education. Hamburg: Author. Retrieved from http://uil. unesco.org/system/files/grale-3.pdf

Walker, M. (2012). Egalitarian policy formulation in lifelong learning: Two models of lifelong education and social justice for young people in Europe. In D. N. Aspin, J. Chapman, K. Evans, \& R. Bagnall (Eds.), Second international handbook of lifelong learning (pp. 181-194). Dordrecht: Springer.

Walters, S., \& Watters, K. (2017). Reflecting on the global report on adult learning and education in the "post-truth society". Adult Education Quarterly, 67(3), 228-237. doi:10.1177/0741713617700675

Werquin, P. (2010). Recognising non-formal and informal learning. Paris: OECD.

Young, M. (2008). Bringing knowledge back in: From social constructivism to social realism in the sociology of education. London: Routledge. 